\title{
Application of Milk-Clotting Protease from Aspergillus oryzae DRDFS13 MN726447 and Bacillus subtilis SMDFS 2B MN715837 for Danbo Cheese Production
}

\author{
Jermen Mamo $\mathbb{D D}^{1,2}$ Paulos Getachew, ${ }^{3}$ Mbugua Samuel Kuria, ${ }^{4}$ and Fassil Assefa ${ }^{1}$ \\ ${ }^{1}$ Microbial, Cellular and Molecular Biology Department, Addis Ababa University, Addis Ababa, Ethiopia \\ ${ }^{2}$ Department of Biology, College of Natural and Computational Science, Debre Berhan University, Debre Berhan, Ethiopia \\ ${ }^{3}$ Centers for Food Science and Nutrition, Addis Ababa University, Addis Ababa, Ethiopia \\ ${ }^{4}$ Food Science, Nutrition and Technology Department, College of Agriculture and Veterinary Science, University of Nairobi, \\ Nairobi, Kenya \\ Correspondence should be addressed to Jermen Mamo; jermenmamo@yahoo.com
}

Received 13 April 2020; Revised 25 May 2020; Accepted 26 May 2020; Published 10 June 2020

Academic Editor: Seyed Mohammad Taghi Gharibzahedi

Copyright (C) 2020 Jermen Mamo et al. This is an open access article distributed under the Creative Commons Attribution License, which permits unrestricted use, distribution, and reproduction in any medium, provided the original work is properly cited.

\begin{abstract}
This study aimed to investigate the efficiency, biochemical composition, and sensory quality of Danbo cheese produced using proteases derived from the fungus and bacterium compared to the commercial product. A fungal enzyme from Aspergillus oryzae DRDFS13MN726447 and a bacterial enzyme from Bacillus subtilis SMDFS 2B MN715837 were produced by solid-state and submerged fermentation, respectively. The crude enzyme from A. oryzae DRDFS13 and B. subtilis SMDFS $2 \mathrm{~B}$ was partially purified by dialysis and used for Danbo cheese production using commercial rennet (CHY-MAX ${ }^{\circledast}$ Powder Extract NB, Christian Hansen, $2235 \mathrm{IMCU} / \mathrm{g}$ ) as a control. The Danbo cheese produced using dialyzed fungal enzyme (E1) (267 U/mL), dialyzed bacterial enzyme (E2) $(522 \mathrm{U} / \mathrm{mL})$, and commercial rennet $(\mathrm{C})$ were analyzed for body property, organoleptic characteristics, and proximate and mineral composition when fresh and after 2 months of ripening. There was no significant difference in the cheese yield $(C=9 \mathrm{~kg}, E 1=8.6 \mathrm{~kg}$, and $E 2=8.9 \mathrm{~kg})$ among the three treatments. The body properties of Danbo cheese produced with the fungal enzyme (E1) were firm and acceptable as the control (C), whereas the Danbo cheese produced by bacterial enzymes has shown a watery body. The overall organoleptic characteristics of Danbo cheese produced by the fungal enzyme (5.3) were similar to control cheese produced by commercial rennet (5.5). Both cheese types were significantly different in organoleptic properties from Danbo cheese produced by the bacterial enzyme (4.9). There was no significant difference $(p>0.05)$ in the proximate composition between the ripened Danbo cheese produced by fungal enzyme and the control cheese except for crude protein content. However, the ripened cheese products showed a significant difference in their mineral composition except for sodium. In conclusion, this study demonstrated that the fungal enzyme from Aspergillus oryzae DRDFS 13 is more appropriate for Danbo cheese production than the bacterial enzyme from Bacillus subtilis SMDFS 2B. However, it requires further application of the enzymes for the production of other cheese varieties.
\end{abstract}

\section{Introduction}

Cheese is one of the most important components of dairy industries and more than 1000 different varieties are produced throughout the world [1]. Generally, different varieties of cheese are industrially produced by using calf rennet [2]. Among which, Danbo cheese is semihard cheese characterized by surface ripening with few round pea-sized holes and distinctive flavor and is consumed after ripening for 2-3 months, but a few variants are allowed to mature for up to 12 months [3]. The flavor of Danbo cheese originates from smear bacteria that develop on the surface during the first weeks of maturation [4]. It is originated and most commonly consumed cheese in Denmark and comprises about $13.2 \%$ of total Danish cheese production $[4,5]$. 
However, the ever-increasing demand for cheese, shortage of calf rennet, and religious restriction on the consumption of calf rennet-based cheese are major challenges for the dairy industries. This necessitated a search for alternatives to calf rennet [6]. With this regard, microbial proteases have become popular and substituted the traditional trend of production. Hence, today only $20-30 \%$ of the world demand for milk-clotting preparation is derived from calf rennet [6,7]. Milk-clotting proteases with high activity and stability at acidic $\mathrm{pH}$ have important industrial applications, specifically as milk-coagulating agents for cheese processing and as flavor enhancers in other food industries [8]. Microbial rennets are replacing calf rennet because of their low production costs, greater biochemical diversity, and easier genetic modification [9]. Accordingly, many fungal and bacterial proteases are widely used for cheese production. For instance, about $60 \%$ of cheese in the USA is manufactured using fungal enzyme sources [9].

However, as to our knowledge, there are limited studies in evaluating the biochemical composition and sensory quality of cheese produced using microbial enzymes. Therefore, this study aimed to investigate the efficiency, biochemical composition, and sensory quality of Danbo cheese produced using proteases derived from the fungus and bacterium compared to the commercial product.

\section{Materials and Methods}

2.1. Microbial Strains Used for Aspartic Protease Enzyme Production. The fungus was isolated from soil samples in Ethiopia and identified as Aspergillus oryzae DRDFS13 using ITS primers (ITS86F (F): 5' - GTG AAT CAT CGA ATC TTT GA- $3^{\prime}$ and ITS4 (R): $5^{\prime}$-TCC TCC GCT TAT TGATAT GC- $\left.3^{\prime}\right)$ at Eurofins Genomics, Germany, after cultural and morphological studies. The bacterium used in the present study was also isolated from Ethiopian soil and identified as Bacillus subtilis SMDFS-2B using 16S rRNA primers (FW: 5'-GCAAGTCGAGCGGACAGATGGGAGC-3'; RV: $5^{\prime}$ AACTCTCGTGGTGTGACGGGCGGTG-3').

2.2. Solid-State Fermentation and Enzyme Extraction from Fungi. Enzyme production was induced by growing the micro-organisms using solid-state fermentation [10]. Briefly, $10 \mathrm{~g}$ of the durum wheat bran substrate (purchased from an open market) was transferred in a $250 \mathrm{~mL}$ Erlenmeyer flask and moistened with $12 \mathrm{~mL}$ of $(0.2 \mathrm{M}) \mathrm{HCl}$. Then, $0.5 \mathrm{~mL}$ of $0.5 \times 10^{6}$ spore suspensions of $A$. oryzae DRDFS13 were inoculated into SSF media and incubated at $30^{\circ} \mathrm{C}$ for 5 days. The nutritional composition of the wheat bran is listed in Table 1.

For enzyme extraction, the fungal culture was dispensed in $100 \mathrm{~mL}$ distilled water $(1: 10$ ratio) and shaken on a rotary shaker (MaxQ 2000 Open-Air Platform Shaker, Thermo Fisher Scientific, USA) at $240 \mathrm{rpm}$ at room temperature. The mixture was centrifuged (Heraeus Pico17/21 centrifuge, Thermo Electron Led, Germany) at $10000 \mathrm{rpm}$ at $4^{\circ} \mathrm{C}$ for
TABle 1: Nutritional composition of wheat bran used for fermentation.

\begin{tabular}{lc}
\hline Nutrients & Mean \pm SD $(\%)$ \\
\hline Moisture & $10.40 \pm 0.20$ \\
Crude fat & $3.77 \pm 0.22$ \\
Crude protein & $12.43 \pm 0.18$ \\
Total ash & $7.40 \pm 1.80$ \\
Crude fiber & $18.77 \pm 0.00$ \\
Total carbohydrate & $47.23 \pm 0.00$ \\
\hline
\end{tabular}

$\mathrm{SD}$, standard deviation.

$10 \mathrm{~min}$ to recover the culture filtrate to be used as crude enzyme source [11].

2.3. Submerged Fermentation and Enzyme Extraction from Bacteria. The medium used for submerged fermentation for bacteria contained $(\mathrm{g} / \mathrm{L})$ the following: glucose, 16.2; wheat bran, 30; $\mathrm{NaCl}, 5 ; \mathrm{MgSO}_{4} \cdot 7 \mathrm{H}_{2} \mathrm{O}, 5 ; \mathrm{KH}_{2} \mathrm{PO}_{4}, 2 ; \mathrm{CaCO}_{3}, 3$; and $\mathrm{pH}$ of 5.2. The bacterium Bacillus subtilis SMDFS $2 \mathrm{~B}$ was inoculated into the medium (inoculum size $/ 0.5 \mathrm{~mL}$ of $\left.0.99 \times 10^{8}\right)$ and incubated at $150 \mathrm{rpm}$ in an orbital shaker (MaxQ 2000 Open-Air Platform Shaker, Thermo Fisher Scientific, USA) at $35^{\circ} \mathrm{C}$ for $72 \mathrm{~h} \mathrm{[12].}$

For enzyme extraction, samples were filtered through a Whatman No 1 filter paper $(90 \mathrm{~mm})$ after $72 \mathrm{~h}$ of cultivation, centrifuged at $10000 \mathrm{rpm}$ for $10 \mathrm{~min}$ at $4^{\circ} \mathrm{C}$, and then the filtrate was used for the enzyme assay [11].

2.4. Detection of Aflatoxins in Fungal Extract. Aflatoxins B1, B2, G1, and G2 were detected by methanol extraction methods (methanol/water 80/20 (v/v) $+\mathrm{NaCl}$ ) at Eurofins Analytik GmbH, Neuländer Kamp 1, 21079 Hamburg, Germany. Then, the extract was diluted with the Tween solution and applied on the immunoaffinity column, followed by washing the column and elution with methanol, and finally diluted with water. The measurement was taken using high-performance liquid chromatography-fluorescence detector (HPLC-FLD) with cobra cell postcolumn derivatization.

2.5. Partial Purification of the Enzyme. The clarified culture supernatant was subjected to dialysis against $20 \mathrm{mM}$ phosphate buffer ( $\mathrm{pH}$ 6.0) utilizing a $10 \mathrm{kDa}$ cutoff membrane. After dialysis, a crude enzyme preparation was concentrated by contacting with carboxymethyl cellulose overnight $\left(4^{\circ} \mathrm{C}\right)$. The crude enzyme was resuspended in sodium phosphate buffer (20 mM, pH 6.0) [13].

2.6. Assay for Milk-Clotting Activity. The milk-clotting activity of the enzyme was undertaken according to Arima et al. [14]. Accordingly, $0.1 \mathrm{~mL}$ of the crude enzyme was added to $1 \mathrm{~mL}$ of reconstituted skimmed milk $\left(\mathrm{Nestle}^{\mathrm{TM}}\right)$ in a $10 \mathrm{~mL}$ test tube preincubated at $35^{\circ} \mathrm{C}$ for $10 \mathrm{~min}$. The reconstituted skimmed milk $\left(\mathrm{Nestle}^{\mathrm{TM}}\right)$ solution consisted of $10 \mathrm{~g}$ dry skimmed milk/100 $\mathrm{mL}$ and $0.01 \mathrm{M} \mathrm{CaCl}_{2}$ $\left(\right.$ AppliChem $\left.{ }^{\mathrm{TM}}\right)$. The appearance of the first clotting flakes 
was visually evaluated and quantified in terms of Soxhlet Units (SU). The endpoint was recorded when discrete particles were discemible. The clotting time $T(\mathrm{~s})$, the period of time starting from the addition of the crude enzyme to the appearance of the first clots and the clotting activity, was calculated using the following formula:

$$
\mathrm{SU}=\frac{(2400 * 5 * D)}{(T * 0.5)},
$$

where $T=$ clotting time $(s)$ and $D=$ dilution of the crude enzyme.

One $\mathrm{SU}$ is expressed as the quantity of the enzyme required to clot $1 \mathrm{~mL}$ of the solution comprising $0.1 \mathrm{~g}$ skimmed milk powder and $0.01 \mathrm{M} \mathrm{CaCl}_{2}$ at $35^{\circ} \mathrm{C}$ within $40 \mathrm{~min}$.

2.7. Protease Activity Assay. The proteolytic activity was assayed according to Arima et al. [14]. Briefly, $0.5 \mathrm{~mL}$ of the enzyme extract was added to $2.5 \mathrm{~mL}$ of $1 \%(\mathrm{w} / \mathrm{v})$ soluble casein in $20 \mathrm{mM}$ potassium phosphate buffer at $\mathrm{pH} 6.5$, and the mixture was incubated in a water bath at $35^{\circ} \mathrm{C}$ for $10 \mathrm{~min}$. After the addition of $2.5 \mathrm{~mL}$ of $0.44 \mathrm{M}$ trichloroacetic acid to terminate the reaction, the mixture was filtered through the Whatman No.1 $(90 \mathrm{~mm})$ filter paper. The filtrate was then mixed with $1 \mathrm{~mL}$ volume of three times diluted 2N Folin/ phenol reagent and $2.5 \mathrm{~mL}$ of $0.55 \mathrm{M}$ sodium carbonate solutions and incubated at $35^{\circ} \mathrm{C}$ for 20 min to detect color development, and optical density (OD) was measured using a spectrophotometer (UV-vis, Liantrinsat, and ModelCF728YW-UK) at $660 \mathrm{~nm}$. One unit (1 U) of enzyme activity was defined as the amount of enzyme that liberated $1 \mu \mathrm{g}$ of tyrosine per $1 \mathrm{~mL}$ in $1 \mathrm{~min}$ :

$$
\mathrm{PA}(\mathrm{U} / \mathrm{mL})=\frac{\mu T y r * V_{t}}{V_{s} * T * V_{a}},
$$

where PA is the protease activity, $\mu$ Try is the $\mu \mathrm{g}$ of tyrosine equivalent released, $V_{t}$ is the total volume of the assay in $\mathrm{mL}$ ( $5 \mathrm{ml}$ of the substrate plus $1 \mathrm{ml}$ of the enzyme plus $5 \mathrm{ml}$ of TCA), $V_{s}$ is the sample volume (i.e., the volume of protease used for the assay in $\mathrm{mL}$ ), $T$ is the reaction time (i.e., time of incubation in minutes, $10 \mathrm{~min}), V_{a}$ is the volume assayed (i.e., final volume of the product used in calorimetric determination).

2.8. Protein Determination. The protein content in the dialyzed enzyme was determined according to the Kjeldahl digestion, distillation, and titration method [15].

2.9. Danbo Cheese Production. Danbo cheese was produced in a dairy pilot plant at the University of Nairobi, College of Agriculture and Veterinary Science, Food Science, Nutrition, and Technology Department. The product was made according to the method described by [16]. Cow milk (30 L) was standardized by skimming (fat removal) and pasteurizing by indirect heating at $62^{\circ} \mathrm{C}$ for $10 \mathrm{~min}$. A total of $30 \mathrm{~L}$ of cow milk divided into three equal portions $(10 \mathrm{~L}$ each). All the three portions were inoculated with $0.6 \%$ fermented milk with mesophilic Streptococcus lactis (MicroKwik Culture ${ }^{\circledR}$,
Carolina). Then, the first portion was renneted using commercial rennet (rennin-coagulate $(2 \mathrm{~g} / 100 \mathrm{~L})$ as a control $(\mathrm{C})$ ). The second and third portions were renneted using the applicable ratio of dialyzed fungal and bacterial enzymes, $5.0 \%$ each, and labeled as E1 and E2, respectively. After treatment with a $40 \% \mathrm{CaCl}_{2}$ solution $(10 \mathrm{~mL} / 100 \mathrm{~mL})$, all treatments were kept for 30 min for clotting. After this, the curd was cut using a cheese knife at a size of $4-6 \mathrm{~mm}$ and stirred for 30-40 min in order to get better cheese grains. After removing the whey, the curd was cooked with hot water at $65^{\circ} \mathrm{C}-39^{\circ} \mathrm{C}$ for $15-20 \mathrm{~min}$, stirred for $30-40 \mathrm{~min}$ for precipitation. Then, the cheese was molded for $20-30 \mathrm{~min}$ and pressed for $2-3 \mathrm{~h}$ by using a metal weighing $30-35 \mathrm{~kg} / \mathrm{kg}$ of cheese. Finally the pressed cheese samples were salted by dipping into $20 \% \mathrm{NaCl}$ for $48 \mathrm{~h}$ and ripened at curing room for 2 months [16]. The whole production design is illustrated in the flowchart in Figure 1. The fresh Danbo cheese was weighed immediately and the yield was calculated as follows [17]:

$$
\text { yield }=\frac{\text { weight of cheese }}{\text { weight of milk }} * 100 \text {. }
$$

2.10. Sensorial Analysis of Danbo Cheese and Rating Its Acceptance. The Danbo cheese was subjected to sensory tests using 13 panelists ( 8 men and 5 women) from dairy pilot plant and staff members of the Food Science, Nutrition, and Technology Department, University of Nairobi. The rating acceptance sensory test was scored for attributes of color, flavor, aroma, texture, and overall acceptability on a 7point hedonic scale where 7 is extremely like and 1 being extremely disliked. The order of product presentation to the panelists was randomized [15]. In brief, sliced cheese (about $10 \mathrm{~g}$ ) of each product was provided to the panelists randomly. Then, after $3 \mathrm{~min}$, they were provided with the next sample following the same procedure.

\subsection{Proximate Analysis of Danbo Cheeses}

2.11.1. Determination of Moisture, Ash, and Fiber Contents. The moisture content was determined according to [15]. Ash content was determined by burning $5 \mathrm{~g}$ of the sample in a muffle furnace at $550^{\circ} \mathrm{C}$ for 3 hours, as per the [15] protocol.

2.11.2. Determination of $p H$ and Titratable Acidity. About $10 \mathrm{~mL}$ of the Danbo cheese sample was dispensed into a conical flask to determine the $\mathrm{pH}$ using the $\mathrm{pH}$ meter (ABS accumet, Fisher Scientific, Singapore). The titratable acidity (TTA) was determined by direct titration with $0.1 \mathrm{M} \mathrm{NaOH}$. The results were converted to lactic acid concentration [6]:

$$
\% \text { lactic acid }=\frac{\text { titre } * 0.9}{\text { weight of sample }},
$$

where titre $=25 \mathrm{~mL}$ - sample of titre.

2.11.3. Determination of Crude Protein and Fat. The crude protein was determined according to the Kjeldahl digestion 
and titration method [15]. The protein content was calculated from the relationship:

$$
\text { total protein }(\%)=\frac{\text { titre } * 6.25 * \text { normality of } \mathrm{NaOH}(0.1 N) * 0.014}{1000 * \text { sample weight }} * 100 \text {, }
$$

where protein conversion factor $=6.25$ for milk, protein $(\%)=\%$ nitrogen $* 6.25$, normality of acid $(\mathrm{HCl})=0.1 \mathrm{~N}$, and sample weight $=1.0 \mathrm{~g}$.

Fat content was also determined by the Soxhlet extraction method according to [15].

\subsubsection{Determination of the Carbohydrate Contents and} Caloric Value. Total carbohydrate content was determined by difference (i.e., subtracting the sum of the percentage moisture, ash, protein, and fat from 100\%). Energy value was quantified indirectly considering the three groups of nutrients, which provide the body with energy carbohydrates, fats, and proteins. One gram of carbohydrate $(\mathrm{C})$, protein $(\mathrm{P})$, and fat $(\mathrm{F})$ will provide 4,4 , and $9 \mathrm{Kcal}$ energy, respectively. Therefore, the total caloric values are calculated as follows:

energy in $\mathrm{Kcal} / 100 \mathrm{~g}$ of the sample $=(P * 4)+(F * 9)+(C * 4)$,

where $P=$ protein content (\%), $F=$ fat content (\%), and $C=$ total carbohydrate $(\%)$.

2.12. Determination of Mineral Content. The concentration of minerals was determined using an atomic absorption spectrophotometer (Analytik Jena Nov AA350, Germany) by the method of Osborne and Voogt (1978) [18]. Briefly, $2.5 \mathrm{~g}$ of samples was transferred to a porcelain dish and heated at $120^{\circ} \mathrm{C}$ for $4 \mathrm{~h}$ on a hot plate until the entire content had become carbonized. The samples were then heated in a furnace at $530^{\circ} \mathrm{C}$ until free of carbon; the residue appeared grayish/white after $8 \mathrm{~h}$. Then, the crude ash was dissolved in $5 \mathrm{~mL}$ of $6 \mathrm{M} \mathrm{HCl}$ on a hot plate for $2 \mathrm{~h}$. Subsequently, $7 \mathrm{~mL}$ of $3 \mathrm{M} \mathrm{HCl}$ was added and heated on a hot plate until the solution boiled. The digested sample was cooled and filtered. Then, $5 \mathrm{~mL}$ of $3 \mathrm{M} \mathrm{HCl}$ was added to the dishes and heated the extract to dissolve the residue. For calcium determination, lanthanum chloride $(10 \% \mathrm{~W} / \mathrm{V})$ was added to both standards and samples to suppress interference from phosphorus. Then, the concentration of the minerals sodium, potassium, magnesium, zinc, manganese, iron, and calcium was analyzed using an atomic absorption spectrophotometer against calibration curves prepared by plotting the absorption or emission values against the metal concentrations in $\mathrm{mg} / 100 \mathrm{~g}$ using the following formula:

$$
\text { metal content }(\mathrm{mg} / 100 \mathrm{~g})=\frac{[(\mathrm{A}-\mathrm{B}) * V]}{10 W},
$$

where $W=$ weight of samples $(\mathrm{g}), V=$ volume of extract $(\mathrm{mL}), A=$ concentration of sample solution $(\mu \mathrm{g} / \mathrm{mL})$, and $B=$ concentration of blank solution $(\mu \mathrm{g} / \mathrm{mL})$.

2.13. Data Analysis. Data were analyzed using SAS software version 9 (Inc. Cary NC USA). The experiments were carried out in triplicate. Statistical comparisons of the mean values were performed by analysis of variance (ANOVA), followed by Duncan's multiple range test. Means were considered significantly different at $p<0.05$.

\section{Results}

3.1. Properties of Partially Purified Microbial Enzymes from Aspergillus oryzae DRDFS13 and Bacillus subtilis SMDFS $2 B$. The physical and chemical properties of the enzymes derived from bacterial and fungal strains in Ethiopia are reported in Table 2. There was no significant difference in titratable acidity (TTA) and total protein content (TP \%) between the enzymes extracted from the two sources $(p<0.05)$. However, the bacterial enzyme had a 2.5- and 7.0-fold higher in milk clotting and protease activities than the fungal enzyme $(p<0.05)$, respectively. In contrast, the MCA/PA ratio was significantly higher $(p<0.05)$ in the fungal enzyme than the bacterial enzyme (Table 2 ).

3.2. Aflatoxin Determination. The aflatoxin types detected from the crude enzyme derived from $A$. oryzae DRDFS13 were B1, B2, G1, and G2 with $<0.1 \mu \mathrm{g} / \mathrm{Kg}$ (Table 3).

3.3. Properties of Danbo Cheese and Its Properties. In this study, Danbo cheese was successfully produced using the enzymes from the two sources. The desirable characteristic of the different cheese products was reported in Table 4. There was no significant difference in the cheese yield upon the three treatments $(p<0.05)$. The cheese made with commercial rennet was firm and acceptable. Similarly, the cheese made with the fungal enzyme was slightly firm and acceptable. However, the bacterial enzyme cheese was watery. In fact, the whey yield was significantly different $(p<0.05)$ upon the three treatments, in the order of CR $>$ DFE $>$ DBE.

3.4. Sensorial Analysis of Fresh Danbo Cheese. The result of acceptability on the basis of the 7-point hedonic scale of the sensory test of the Danbo cheeses was reported in Table 5. The color score was in the accepted order of $\mathrm{CR}>\mathrm{DFE}>\mathrm{DBE}$. There was a significant difference in flavor 


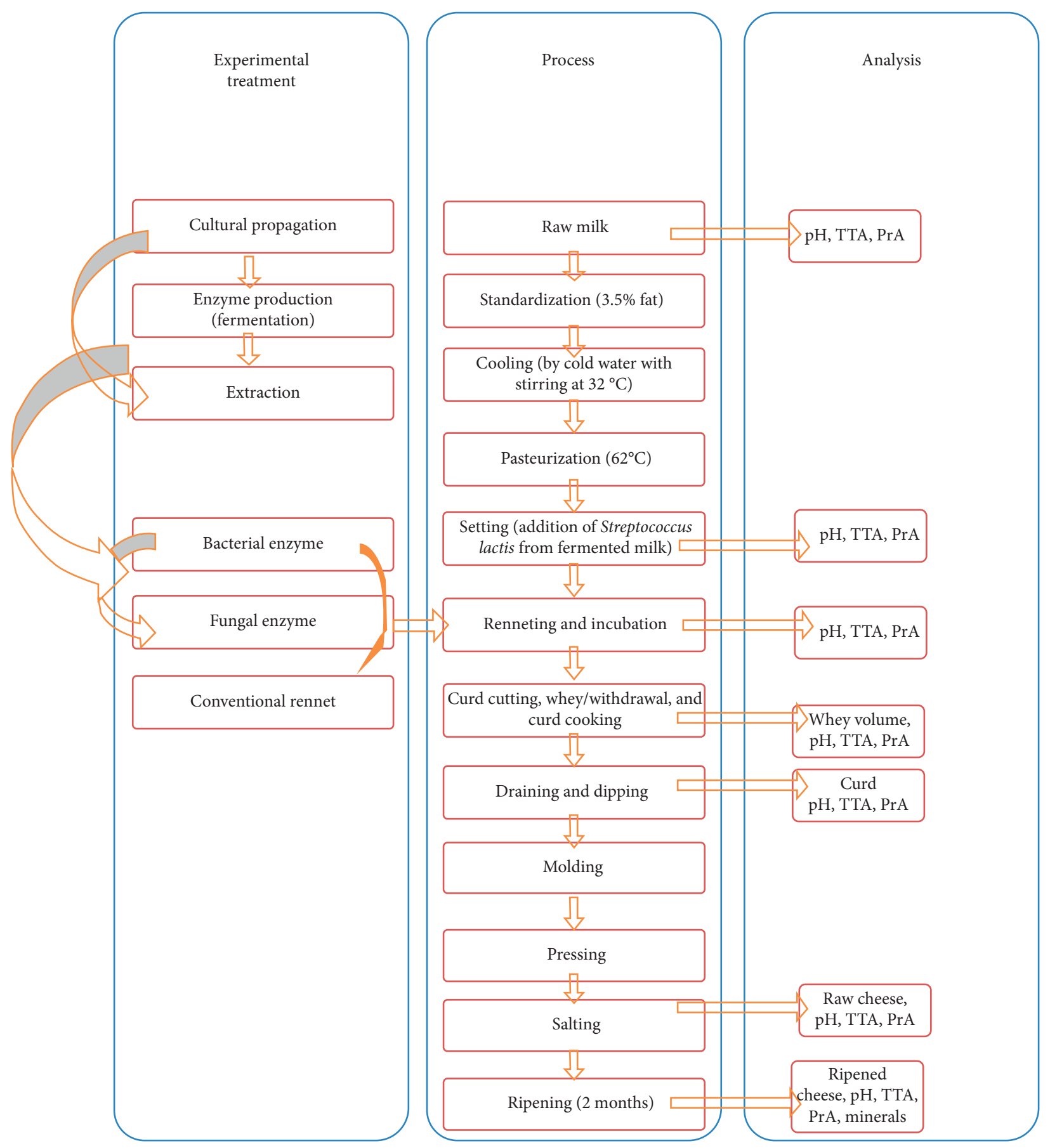

Figure 1: Production and analysis design for Danbo cheese.

among the treatments. However, there was no significant difference in odor and texture scores between the three kinds of cheese.

3.5. $p H$ and TTA Liquid Samples Produced during Danbo Cheese Production. The $\mathrm{pH}$ and titratable acidity (TTA) of the three liquid products are shown in Table 6. The inoculation of the raw milk with mesophilic S. lactis (LAB) reduced the $\mathrm{pH}$ of the milk by $0.7-1.0$ units. The renneting with the crude fungal and the commercial enzymes slightly decreased the $\mathrm{pH}(0.8-1.0)$. Also, there was a significant difference in titratable acidity (TTA) among the treatments (Table 6).

3.6. Proximate Composition of Liquid Samples Produced during Danbo Cheese Production. The addition of the LAB (Streptococcus lactis) drastically decreased the crude fat content by $12-30 \%$, while the crude enzymes from the fungus and bacterium slightly decreased the crude fat content after renneting. The renneting treatment also 
TABLE 2: Characteristics of the dialyzed bacterial and fungal enzymes.

\begin{tabular}{lcc}
\hline Parameters & $\begin{array}{c}\text { Dialyzed bacterial } \\
\text { enzyme }\end{array}$ & $\begin{array}{c}\text { Dialyzed fungal } \\
\text { enzyme }\end{array}$ \\
\hline pH & $5.96 \pm 0.00^{\mathrm{a}}$ & $4.81 \pm 0.01^{\mathrm{b}}$ \\
TTA (\%) & $0.04 \pm 0.00^{\mathrm{b}}$ & $0.07 \pm 0.00^{\mathrm{a}}$ \\
TP (\%) & $0.30 \pm 0.00^{\mathrm{a}}$ & $0.52 \pm 0.02^{\mathrm{a}}$ \\
MCA (U/mL) & $521.99 \pm 11.35^{\mathrm{a}}$ & $266.70 \pm 2.96^{\mathrm{b}}$ \\
PA (U/mL) & $1623.62 \pm 6.10^{\mathrm{a}}$ & $231.24 \pm 4.80^{\mathrm{b}}$ \\
Ratio (MCA/ & $0.32 \pm 0.01^{\mathrm{b}}$ & $1.15 \pm 0.01^{\mathrm{a}}$ \\
PA) & & \\
\hline
\end{tabular}

TTA, titratable acidity; TP, total protein; MCA, milk-clotting activity; PA, protease activity. Data are expressed as mean $\pm S D(n=3)$ on a wet basis. Means in the same row with different superscripts are significantly different at $p<0.05$.

decreased the carbohydrate and energy contents of the samples, where the decrease in the latter was higher with the commercial rennet than the crude enzyme treatments (Table 7).

3.7. pH and TTA of Danbo Cheese. The fresh Danbo cheeses produced in all the three treatments were salted by dipping into $20 \% \mathrm{NaCl}$ solution for $48 \mathrm{~h}$ and ripened in the curing room at $10^{\circ} \mathrm{C}$ for 2 months. In all cases, $\mathrm{pH}$ and TTA significantly increased in the ripened cheese irrespective of the treatments (Table 8).

\subsection{Proximate Composition of Fresh and Ripened Danbo} Cheeses. Moisture content decreased in salted and ripened cheese, in which in the former the rate was higher. Among the three fresh cheese types, CR had the highest protein content followed by DBE and DFE, respectively. The crude protein content in the ripened cheese was in the order of $\mathrm{CR}>\mathrm{DFE}>\mathrm{DBE}$. In contrast, there was no significant difference in crude protein content among the three salted kinds of cheese. Among the three cheese types, CR ripened cheese had the highest crude protein content (Table 9). Salted CR and DFE cheese types had higher crude fat content, while the DBE salted cheese had the lowest amount. There was no significant difference in the crude fat content among all the three ripened cheese types $(p<0.05)$. The ash content in the fresh DBE was significantly lower than the amount in the other two cheese types. In all the cases, the salted cheese had higher ash content than the fresh and ripened cheeses (i.e., $C R>D B E>D F E$ ) except for DFE. The ripened cheese types had shown the highest carbohydrate contents in all the three treatments. The salted cheese types had the highest total caloric value compared with the fresh and ripened cheese.

3.9. Mineral Contents of Ripened Danbo Cheese. The ripened cheese products showed a significant difference in their mineral composition except for sodium (Table 10). Potassium and zinc concentrations were the highest in DBE while calcium and manganese concentrations were the highest in DFE cheese. Zinc and potassium concentrations were higher in the microbial enzyme-made cheeses than in the control.
TABLE 3: Aflatoxin concentration of the crude enzyme extract from A. oryzae DRDFS13.

\begin{tabular}{lc}
\hline Types of aflatoxins & Concentration $(\mu \mathrm{g} / \mathrm{Kg})$ \\
\hline $\mathrm{B}_{1}$ & $<0.1$ \\
$\mathrm{~B}_{2}$ & $<0.1$ \\
$\mathrm{G}_{1}$ & $<0.1$ \\
$\mathrm{G}_{2}$ & $<0.1$ \\
Total & $<0.4$ \\
\hline
\end{tabular}

Similarly, calcium content was higher in the DFE- and DBEmade cheese than in the control. Manganese was not detected in the control cheese, but significantly higher concentration was found in the DFE and DBE cheese, respectively. The magnesium content in CR cheese was the highest. Iron was not detected in all the samples.

In the present study, the average value of $\mathrm{Na}, \mathrm{K}, \mathrm{Ca}$, and $\mathrm{Mg}$ recorded from ripened Danbo cheeses was between $357-366 \mathrm{mg} / 100 \mathrm{~g}, 2.1-3.8 \mathrm{mg} / 100 \mathrm{~g}, 3.7-10.9 \mathrm{mg} / 100 \mathrm{~g}$, and $7.0-49.8 \mathrm{mg} / 100 \mathrm{~g}$, respectively. The average value of $\mathrm{Zn}$, $\mathrm{Mn}$, and $\mathrm{Fe}$ recorded from ripened Danbo cheeses were between $0.1-0.8 \mathrm{mg} / 100 \mathrm{~g}, 0.0-23.2 \mathrm{mg} / 100 \mathrm{~g}$, and $0.00 \mathrm{mg} /$ $100 \mathrm{~g}$, respectively (Table 10 ).

\section{Discussion}

The aflatoxin content of the crude enzyme from A. oryzae DRDFS 13 used for Danbo cheese production was below the standard limit set by the European Union [19]. This indicated the safety of the crude enzyme for application in food production. In fact, other studies also marked that enzymes extracted from Aspergillus species are generally recognized as safe (GRAS) [20-23]. Thus, it can be used as a rennin substitute in the coagulation of milk and manufacture of cheese [2]. Similarly, the milk-clotting enzyme obtained from Rhizomucor miehei NRRL 2034 used for white soft cheese was free from aflatoxins B1, B2, G1, and G2 in the study by [2]. Fazouane-Naimi et al. [24] also reported that the culture supernatants from $A$. niger FFB1 used for cheese production were free from ochratoxin A (OTA).

The raw cow milk used for the Danbo cheese making had $\mathrm{pH}$, TTA, water, crude protein, crude fat, total ash, and total carbohydrate values of $6.65,0.12 \%, 88.93 \%, 2.96 \%, 4 \%$, $0.48 \%$, and $3.64 \%$, respectively. Similar chemical composition of cow's milk used for the production of white pickled and Prato cheeses was reported by Çepepoğlu and GülerAkın [25, 26], respectively.

Substantial volumes of whey were discarded during the Danbo cheese production. The highest whey yield was obtained from commercial rennet followed by fungal and bacterial enzymes, respectively. The physico-chemical characteristics of the whey in the present study were similar, with whey samples reported by Omole et al. [27]. Similarly, the highest amount of cheese was yielded from the commercial rennet enzyme as compared to fungal and bacterial enzymes. In contrast, a higher yield of UF-Domiati cheese was obtained by the M. mucedo KP736529 enzyme (E-cheese) than control cheese produced by commercial calf rennet [28]. The yield of 
TABLE 4: Cheese and whey yield from the commercial rennet, dialyzed fungal, and dialyzed bacterial enzymes.

\begin{tabular}{lccc}
\hline Treatment & Whey yield (\%) & Cheese yield (\%) & Body properties \\
\hline Commercial rennet & 40.0 & 9.0 & Firm and acceptable \\
Dialyzed fungal enzyme & 37.0 & 8.6 & Slightly firm and acceptable \\
Dialyzed bacterial enzyme & 27.5 & 8.9 & Watery body \\
\hline
\end{tabular}

TABLE 5: Sensorial characteristics of fresh Danbo cheese.

\begin{tabular}{lccc}
\hline Parameters & Danbo cheese produced by CR & Danbo cheese produced by DFE & Danbo cheese produced by DBE \\
\hline Color (7\%) & $5.63 \pm 0.71^{\mathrm{a}}$ & $4.79 \pm 1.13^{\mathrm{b}}$ & $4.28 \pm 1.26^{\mathrm{c}}$ \\
Odor (7\%) & $5.64 \pm 1.09^{\mathrm{a}}$ & $5.64 \pm 1.23^{\mathrm{a}}$ & $4.99 \pm 1.32^{\mathrm{a}}$ \\
Flavor (7\%) & $5.36 \pm 0.88^{\mathrm{a}}$ & $4.98 \pm 1.12^{\mathrm{ab}}$ & $4.82 \pm 1.03^{\mathrm{b}}$ \\
Texture (7\%) & $5.54 \pm 0.94^{\mathrm{a}}$ & $5.34 \pm 1.10^{\mathrm{a}}$ & $5.30 \pm 1.10^{\mathrm{a}}$ \\
Overall acceptability (7\%) & $5.54^{\mathrm{a}}$ & $5.29^{\mathrm{a}}$ & $4.84^{\mathrm{b}}$ \\
\hline
\end{tabular}

Data are expressed as mean \pm SD. Mean values in the same row with different superscripts are significantly different at $p<0.05$. CR, commercial rennet; DFE, dialyzed fungal enzyme; DBE, dialyzed bacterial enzyme.

TABLE 6: $\mathrm{pH}$ and TTA of raw milk and liquid samples during Danbo cheese processing.

\begin{tabular}{|c|c|c|c|c|c|c|c|}
\hline \multirow[b]{2}{*}{ Parameters } & \multicolumn{7}{|c|}{ Liquid samples produced during Danbo cheese processing } \\
\hline & Raw milk & $\begin{array}{c}\text { CR after LAB } \\
\text { addition }\end{array}$ & $\begin{array}{l}\text { CR after } \\
\text { renneting }\end{array}$ & $\begin{array}{c}\text { DFE after LAB } \\
\text { addition }\end{array}$ & $\begin{array}{l}\text { DFE after } \\
\text { renneting }\end{array}$ & $\begin{array}{c}\text { DBE after LAB } \\
\text { addition }\end{array}$ & $\begin{array}{l}\text { DBE after } \\
\text { renneting }\end{array}$ \\
\hline $\mathrm{pH}$ & $6.65 \pm 0.03^{\mathrm{a}}$ & $5.95 \pm 0.01^{\mathrm{c}}$ & $5.82 \pm 0.02^{\mathrm{d}}$ & $5.70 \pm 0.02^{\mathrm{e}}$ & $5.60 \pm 0.03^{\mathrm{f}}$ & $5.70 \pm 0.00^{\mathrm{e}}$ & $5.87 \pm 0.01^{\mathrm{d}}$ \\
\hline TTA & $0.12 \pm 0.00^{\mathrm{d}}$ & $0.14 \pm 0.00^{\mathrm{c}}$ & $0.12 \pm 0.00^{\mathrm{d}}$ & $0.15 \pm 0.00^{\mathrm{b}}$ & $0.15 \pm 0.00^{\mathrm{b}}$ & $0.16 \pm 0.00^{\mathrm{a}}$ & $0.14 \pm 0.00^{\mathrm{c}}$ \\
\hline
\end{tabular}

Data are expressed as mean $\pm \mathrm{SD}(\mathrm{n}=3)$. Mean values with the different letters within a row are significantly different at $p<0.05$. LAB, lactic acid bacteria; TTA, titratable acidity; CR, commercial rennet; DFE, dialyzed fungal enzyme; DBE, dialyzed bacterial enzyme.

TABle 7: Proximate composition of raw milk and liquid samples during Danbo cheese processing.

\begin{tabular}{|c|c|c|c|c|c|c|c|}
\hline \multirow[b]{2}{*}{ Parameters } & \multicolumn{7}{|c|}{ Liquid samples were taken during Danbo cheese processing } \\
\hline & Raw milk & $\begin{array}{c}\text { CR after LAB } \\
\text { addition }\end{array}$ & $\begin{array}{l}\text { CR after } \\
\text { renneting }\end{array}$ & $\begin{array}{l}\text { DFE after LAB } \\
\text { addition }\end{array}$ & $\begin{array}{l}\text { DFE after } \\
\text { renneting }\end{array}$ & $\begin{array}{c}\text { DBE after LAB } \\
\text { addition }\end{array}$ & $\begin{array}{l}\text { DBE after } \\
\text { renneting }\end{array}$ \\
\hline Moisture (\%) & $88.93 \pm 0.01^{\mathrm{de}}$ & $88.62 \pm 0.05^{\mathrm{de}}$ & $90.73 \pm 0.05^{b}$ & $88.40 \pm 0.02^{\mathrm{e}}$ & $89.73 \pm 0.38^{c}$ & $88.81 \pm 0.01^{\mathrm{de}}$ & $89.18 \pm 0.31^{\mathrm{dc}}$ \\
\hline $\begin{array}{l}\text { Crude protein } \\
\text { (\%) }\end{array}$ & $2.96 \pm 0.01^{\mathrm{cd}}$ & $3.15 \pm 0.01^{\mathrm{a}}$ & $3.06 \pm 0.01^{\mathrm{ab}}$ & $2.87 \pm 0.01^{\mathrm{de}}$ & $2.85 \pm 0.02^{\mathrm{e}}$ & $2.87 \pm 0.01^{\mathrm{de}}$ & $0.07^{\mathrm{bc}}$ \\
\hline Crude fat $(\%)$ & $4.00 \pm 0.00^{\mathrm{a}}$ & $2.81 \pm 0.01^{\mathrm{e}}$ & $2.00 \pm 0.00^{\mathrm{g}}$ & $3.51 \pm 0.00^{\mathrm{b}}$ & $3.05 \pm 0.05^{\mathrm{d}}$ & $3.23 \pm 0.08^{\mathrm{c}}$ & $2.70 \pm 0.00^{\mathrm{f}}$ \\
\hline Ash (\%) & $0.48 \pm 0.01^{\mathrm{e}}$ & $0.62 \pm 0.01^{\mathrm{c}}$ & $0.79 \pm 0.01^{\mathrm{a}}$ & $0.69 \pm 0.00^{\mathrm{b}}$ & $0.70 \pm 0.00^{\mathrm{b}}$ & $0.48 \pm 0.01^{\mathrm{e}}$ & $0.64 \pm 0.02^{\mathrm{c}}$ \\
\hline $\begin{array}{l}\text { Carbohydrates } \\
\text { (\%) }\end{array}$ & $3.64 \pm 0.01^{\mathrm{f}}$ & $4.33 \pm 0.01^{\mathrm{d}}$ & $3.40 \pm 0.01^{\mathrm{g}}$ & $4.58 \pm 0.01^{b c}$ & $4.07 \pm 0.05^{\mathrm{e}}$ & $4.53 \pm 0.02^{c}$ & $4.32 \pm 0.11^{\mathrm{d}}$ \\
\hline $\begin{array}{l}\text { Energy (Kcal/ } \\
100 \mathrm{~g})\end{array}$ & $62.38 \pm 0.02^{\mathrm{a}}$ & $55.22 \pm 0.08^{\mathrm{d}}$ & $43.84 \pm 0.08^{f}$ & $60.85 \pm 0.38^{\mathrm{b}}$ & $55.13 \pm 0.17^{\mathrm{d}}$ & $58.61 \pm 0.65^{\mathrm{c}}$ & $53.76 \pm 0.74^{\mathrm{e}}$ \\
\hline
\end{tabular}

LAB, lactic acid bacteria; TTA, titratable acidity; CR, commercial rennet; DFE, dialyzed fungal enzyme; DBE, dialyzed bacterial enzyme. The mean is the average of three measurements and expressed as mean \pm SD. Means with the same letters within the row are not significantly different while means with different letters within the row are significantly different at $p<0.05$.

TABle 8: pH and TTA of Danbo cheese (before press, salted, and ripened).

\begin{tabular}{|c|c|c|c|c|c|c|c|c|c|}
\hline Par & $\begin{array}{c}\text { CR fresh } \\
\text { cheese } \\
\text { before press }\end{array}$ & $\begin{array}{l}\text { CR salted } \\
\text { cheese }\end{array}$ & $\begin{array}{l}\text { CR ripened } \\
\text { cheese }\end{array}$ & $\begin{array}{c}\text { DFE fresh } \\
\text { cheese } \\
\text { before press }\end{array}$ & $\begin{array}{l}\text { DFE salted } \\
\text { cheese }\end{array}$ & $\begin{array}{l}\text { DFE } \\
\text { ripened } \\
\text { cheese }\end{array}$ & $\begin{array}{l}\text { DBE fresh } \\
\text { cheese } \\
\text { before press }\end{array}$ & $\begin{array}{r}\text { DBE } \\
\text { ch }\end{array}$ & $\begin{array}{l}\mathrm{D} \\
\text { ripe } \\
\text { che }\end{array}$ \\
\hline & & & & & & 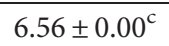 & & & 7.34 \\
\hline ГTA & $0.05 \pm 0.00^{\mathrm{e}}$ & $0.03 \pm 0.00$ & $0.11 \pm 0.00^{\mathrm{c}}$ & $0.06 \pm 0.00^{\mathrm{d}}$ & $0.02 \pm 0.00^{\mathrm{g}}$ & $0.27 \pm 0.00^{\mathrm{a}}$ & $0.05 \pm 0.00^{\mathrm{e}}$ & $0.03 \pm 0.00^{f}$ & $0.16 \pm 0.00^{\mathrm{b}}$ \\
\hline
\end{tabular}

Data are expressed as mean $\pm \mathrm{SD}(\mathrm{n}=3)$. Mean values within a row with different superscripts are significantly different at $p<0.05$. TTA, titratable acidity; CR, commercial rennet; DFE, dialyzed fungal enzyme; DBE, dialyzed bacterial enzyme.

semihard cheese produced using commercial chymosin was slightly higher than the report in the present study [29].

As per the rating acceptance sensory test on the Danbo cheeses, the color and flavor score was in the accepted order of $\mathrm{CR}>\mathrm{DFE}>\mathrm{DBE}$. However, there was no significant difference in odor and texture between the three kinds of cheese. The less rating acceptance score for the DBE could be due to the nonspecific catalytic activity of the bacterial 


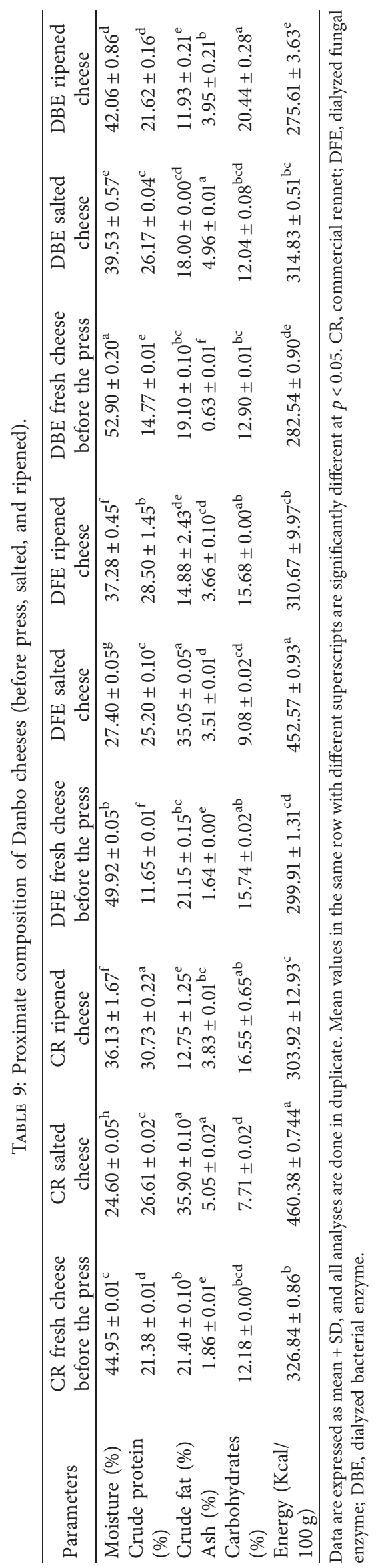


TABLE 10: Mineral concentrations of ripened cheese (after 2 months of ripening).

\begin{tabular}{|c|c|c|c|c|c|c|c|}
\hline \multirow{2}{*}{ Types of cheese } & \multicolumn{7}{|c|}{ Mineral concentration in $\mathrm{mg} / 100 \mathrm{~g}$} \\
\hline & Sodium & Potassium & Calcium & Magnesium & Zinc & Manganese & Iron \\
\hline CR cheese & $356.50 \pm 0.02$ & $2.10 \pm 0.01$ & $3.74 \pm 0.01$ & $49.80 \pm 0.04$ & $0.10 \pm 0.07$ & ND & ND \\
\hline DFE cheese & $364.07 \pm 0.00$ & $2.88 \pm 0.00$ & $10.91 \pm 0.00$ & $24.17 \pm 0.01$ & $0.56 \pm 0.02$ & $23.21 \pm 0.44$ & ND \\
\hline DBE cheese & $366.31 \pm 0.02$ & $3.78 \pm 0.00$ & $9.11 \pm 0.01$ & $6.99 \pm 0.031$ & $0.834 \pm 0.08$ & $6.29 \pm 0.20$ & $\mathrm{ND}$ \\
\hline
\end{tabular}

$\mathrm{ND}$, not detected; CR, commercial rennet; DFE, dialyzed fungal enzyme; DBE, dialyzed bacterial enzyme. Data are expressed as mean \pm SD $(n=3)$.

enzyme on casein as compared to the fungal enzyme [30]. The nonspecific activity and heat-stable property of proteases led to the development of bitterness in cheese [31].

In previous studies, white soft cheese produced using a milk-clotting enzyme from M. miehei NRRL 3420 [2], UF-soft cheese produced by the Rhizomucor miehei NRRL 2034 coagulant [7], fresh cheese manufactured with the A. niger FFB1 enzyme [24], and fresh goat cheese produced by the M. miehei microbial coagulant [32] had similar organoleptic characteristics with control cheese produced by calf rennet. Also, Çepepoğlu and Güler-Akın [25] reported higher sensory acceptability of fresh Turkish white cheese made using $A$. niger var awamori recombinant chymosin than commercially made cheese. Thus, the fungal enzymes might be considered as potential substituents for the commercial rennet.

The results also showed that, the titratable acidity of Danbo cheeses decreased after salting but increased after ripening in all the experimental and control treatments. The decrease in titratable acidity after salting could be associated with the diffusion of lactic acid from the cheese into the brine [25]. Similarly, the titratable acidity of all Turkish white cheeses produced using different coagulants decreased during a storage time of 30 days and then increased [25]. Similarly, the total acidity of experimental Domiati cheese manufactured using the M. mucedo KP736529 enzyme and control cheese was gradually increased during ripening for 60 days [28].

Among the three fresh cheese types, CR had the highest protein content followed by DBE and DFE, respectively. The crude protein content in the ripened cheese was in the order of CR $>$ DFE $>$ DBE. Similarly, higher total nitrogen content was reported in a control cheese (Domiati cheese manufactured by calf rennet) than experimental cheese (Domiati cheese manufactured with the M. mucedo KP736529 enzyme) [28]. On the other hand, the UF-white soft cheese manufactured by the B. stearothermophilus coagulant [33], fresh white soft cheese made with Rhizomucor miehei NRRL 2034 rennet [2], and fresh goat cheese produced by the $M$. miehei coagulant [32] revealed comparable protein content with control cheese produced by calf rennet.

Salted CR and DFE cheese types had higher crude fat content, while the DBE salted cheese had the lowest amount. The ash content in the fresh DBE was significantly lower than the amount in the other two cheese types. In all the cases, the salted cheese had higher ash content than the fresh and ripened cheeses (i.e., $\mathrm{CR}>\mathrm{DBE}>\mathrm{DFE}$ ). The salted cheese types had the highest total energy compared with the fresh and ripened cheese. This could be due to the removal of moisture content during salting which leads to an increase in crude fat and crude protein contents of the cheese.
In the present study, the crude fat contents were increased after salting but decreased after ripening for Danbo cheeses produced from commercial rennet and the dialyzed fungal enzyme. However, the crude fat content was continuously decreased after salting and ripening for Danbo cheese produced using the dialyzed bacterial enzyme. The highest crude fat was noticed from ripened Danbo cheese produced by the fungal enzyme, whereas the lowest crude fat was recorded from ripened Danbo cheese produced by a bacterial enzyme. The lipid contents (5.5-10\%) noticed from cream cheeses produced using the purified milk-clotting enzyme by Bacillus sp. P45 were lower than the present study [6]. The low lipid content noticed in cream cheese could be attributed to the high moisture content of the cream cheese as compared to Danbo cheese.

In contrast to the present study, the fat contents of Turkish white cheeses remained steady in all treatments throughout the ripening period [25]. In other studies, a higher fat content was detected in control cheese than cheese produced by the fungal enzyme [28]. However, the fat contents of UF-white soft cheese produced using the $B$. stearothermophilus coagulant [33], Prato cheese produced by the Thermomucor indicae-seudaticae N31 enzyme [26], white soft cheese produced by the Rhizomucor miehei NRRL 2034 rennet enzyme [2], and fresh goat cheese produced by the M. miehei coagulant [32] were similar with control cheese produced using the commercial enzyme.

The total carbohydrates contents of Danbo cheese were decreased after salting and increased after ripening, whereas the total caloric value $(\mathrm{Kcal} / 100 \mathrm{~g})$ produced from Danbo cheeses was increased after salting but decreased after ripening for all the three treatments. The increase in energy after salting could be due to the increase in crude fat content due to the removal of moisture content.

The highest carbohydrate content was detected from ripened Danbo cheese produced using the bacterial enzyme in comparison with the fungal enzyme and commercial rennet. However, the highest caloric value in Kcal was obtained from ripened Danbo cheese made by the fungal enzyme. The carbohydrate contents of 5.34 to $9.01 \%$ and caloric value $(113.14-139.16 \mathrm{Kcal} / 100 \mathrm{~g})$ obtained from cream cheeses produced using the purified milk-clotting enzyme by Bacillus sp. P45 are lower than reported in the present study [6]. The low nutrient noticed in cream cheese could be attributed to the high moisture contents of the cheese.

In the present study, both the experimental and control Danbo cheeses showed variable ash contents. However, the 
highest ash content was recorded from fresh salted cheese produced using commercial rennet. In contrast to this study, higher ash content was noticed from Prato cheese produced by the Thermomucor indicae-seudaticae N31 protease as compared to control cheese produced using a commercial coagulant [34].

The crude fiber was not detected in both experimental and control Danbo cheeses. The absence of fiber in the Danbo cheese could be associated with the limited use of only milk and enzyme as ingredients for Danbo cheese production rather than different flours. In contrast, the fiber content of 3.00 to $4.96 \%$ was detected from cream cheeses produced using the purified milk-clotting enzyme by $\mathrm{Ba}$ cillus sp. P45 [6].

In the present study, the average values of $\mathrm{Na}, \mathrm{K}, \mathrm{Ca}$, and $\mathrm{Mg}$ recorded from ripened Danbo cheeses were between $356-366 \mathrm{mg} / 100 \mathrm{~g}, 2.1-3.8 \mathrm{mg} / 100 \mathrm{~g}, 3.7-10.9 \mathrm{mg} / 100 \mathrm{~g}$, and $7.0-49.8 \mathrm{mg} / 100 \mathrm{~g}$, respectively. The concentration of sodium was the highest in all three types of cheeses. This may be due to diffusion of sodium into cheeses during dipping of cheese into $20 \% \mathrm{NaCl}$.

Similarly, the $\mathrm{Na}$ content $(462 \mathrm{mg} / 100 \mathrm{~g})$ [35] noticed from full-fat cheese and $\mathrm{K}$ and Ca contents (K:1.0 mg/100 g and Ca: $11.5 \mathrm{mg} / 100 \mathrm{~g}$ ) [17] detected from mozzarella cheese were equivalent with this study. The $\mathrm{Mg}$ content $(27 \mathrm{mg} /$ $100 \mathrm{~g})$ [36], (406 ppm) [37], (40 mg/100 g) [38], (33 mg/ $100 \mathrm{~g})$ [35], and $(41 \mathrm{mg} / 100 \mathrm{~g})$ [39] detected from the hard cheese cantal, from ripened cow's, ewe's, and goat's cheeses, double crème white brined cheese, full-fat cheese, and Pecorino d'Abruzzo cheeses was also comparable with the report in the present study.

However, the major mineral composition recorded from ripened Prato cheese (Na: 6.5, K: 1.2, Ca: 13, and Mg: $0.5 \mathrm{~g} /$ $\mathrm{kg}$ ) [40], hard cheese cantal (Na: 682, K: 93, and Ca: $668 \mathrm{mg} /$ $100 \mathrm{~g}$ ) [36], ripened cow's, ewe's, and goat's cheeses (Na:7.9, $\mathrm{K}: 1.2$, and $\mathrm{Ca}: 7.9 \mathrm{~g} / \mathrm{Kg}$ ) [37], double crème white brined cheese (Na: 995, K:57, and Ca: $378 \mathrm{mg} / 100 \mathrm{~g}$ ) [38], full-fat cheese produced by the high-pH method (K: 107 and Ca: 729) [35], Pecorino d'Abruzzo cheeses (Na: 581, K: 84, and Ca: $669 \mathrm{mg} / 100 \mathrm{~g}$ ) [39], and ripened cheddar cheese (Na:675, $\mathrm{K}: 85$, and Ca:739 mg/100 g) [41] was higher than reported in the present study.

The average values of $\mathrm{Zn}, \mathrm{Mn}$, and Fe recorded from ripened Danbo cheeses were between $0.104-0.834 \mathrm{mg} /$ $100 \mathrm{mg}, 0.00-23.205 \mathrm{mg} / 100 \mathrm{~g}$, and $0.00 \mathrm{mg} / 100 \mathrm{~g}$, respectively. The $\mathrm{Zn}$ content noticed from double crème white brined cheese $(2.0 \mathrm{mg} / 100 \mathrm{~g})$ was comparable with this study [38]. On the other hand, the $\mathrm{Zn}(31 \mathrm{mg} / \mathrm{kg})$ and $\mathrm{Fe}(3.0 \mathrm{mg} /$ $\mathrm{kg}$ ) contents recorded from ripened Prato cheese are higher than the present study, while the Mn content $(0.26 \mathrm{mg} / 100 \mathrm{~g})$ is lower than this study [40]. Different from the present study, $0.7 \mathrm{mg} / 100 \mathrm{~g}$ of Fe was noticed from full-fat cheese produced by a high-pH method [35].

\section{Conclusion}

Therefore, the results obtained from the body property, organoleptic characteristics, proximate composition, and partly from mineral composition revealed that the fungal enzyme from Aspergillus oryzae DRDFS 13 is more appropriate for Danbo cheese production than the bacterial enzyme from Bacillus subtilis SMDFS 2B.

\section{Data Availability}

The data used in this study are publicly available wherever possible-as open as possible and as closed as necessary.

\section{Conflicts of Interest}

The authors declare no conflicts of interest.

\section{Acknowledgments}

The authors would like to acknowledge the Department of Microbial, Cellular, and Molecular Biology of Addis Ababa University; Downstream Processing Laboratory, Department of Life Sciences and Chemistry, Jacobs University, Bremen, Germany; and Food Science, Nutrition, and Technology Department, College of Agriculture and Veterinary Science, University of Nairobi, Kenya, for the facilitation of laboratory space and provision of facilities. This work was supported by the Department of Microbial, Cellular, and Molecular Biology, Addis Ababa University. Partial support for this study was provided from the ARISE Program.

\section{References}

[1] Z. Erbay, N. Koca, F. Kaymak-ertekin, and M. Ucuncu, "Optimization of spray drying process in cheese," Food Bioprod Process, vol. 93, pp. 156-165, 2014.

[2] A. E. A. Amer, M. I. Hashem, M. E. Amer, and A. M. Gomaa, "Using sweet whey for production of milk clotting enzyme by Mucor miehei NRRL 3420 in production of white soft cheese," Middle East Journal of Applied Sciences, vol. 5, no. 4, pp. 1068-1081, 2015.

[3] J. Sorensen and C. Benfeldt, "Comparison of ripening characteristics of Danbo cheeses from two dairies," International Dairy Journal, vol. 11, pp. 355-362, 2001.

[4] J. S. Madsen and Y. Ardö, "Exploratory study of proteolysis, rheology and sensory properties of Danbo cheese with different fat contents," International Dairy Journal, vol. 11, no. 4-7, pp. 423-431, 2001.

[5] M. Ryssel, P. Johansen, W. A. Al-soud, S. Sørensen, N. Arneborg, and L. Jespersen, "Microbial diversity and dynamics throughout manufacturing and ripening of surface ripened semi-hard Danish Danbo cheeses investigated by culture-independent techniques," International Journal of Food Microbiology, vol. 215, pp. 124-130, 2015.

[6] A. C. Lemes, Y. Pavón, S. Lazzaroni, S. Rozycki, A. Brandelli, and S. J. Kalil, "A new milk-clotting enzyme produced by Bacillus sp. P45 applied in cream cheese development," LWT-Food Science and Technology, vol. 66, pp. 217-224, 2016.

[7] H. M. Abbas, M. S. Foda, J. M. Kassem, H. M. Bayomi, and M. E. Moharam, "Production of white soft cheese using fungal coagulant produced by solid state fermentation technique," World Applied Sciences Journal, vol. 25, no. 6, pp. 939-944, 2013. 
[8] V. Mandujano-González, L. Villa-tanaca, M. A. Anduchoreyes, and Y. Mercado-flores, "Secreted fungal aspartic proteases: a review," Revista Iberoamericana de Micología, vol. 33, no. 2, pp. 76-82, 2016.

[9] H. Wehaidy, M. Abdel-Naby, W. Shousha, M. Y. El Mallah, and M. Shawky, "Optimization of the production and characterization of milk-clotting enzyme from Bacillus subtilis isolated from marine sponge," Egyptian Pharmaceutical Journal, vol. 15, no. 3, pp. 158-166, 2016.

[10] H. M. Fernández-Lahore, E. R. Fraile, and O. Cascone, "Acid protease recovery from a solid-state fermentation system," Journal of Biotechnology, vol. 62, no. 2, pp. 83-93, 1998.

[11] G. G. D. Silveira, G. M. D. Oliveira, E. J. Ribeiro, R. Monti, and J. Contiero, "Microbial rennet produced by Mucor miehei in solid-state and submerged fermentation," Brazilian Archives of Biology and Technology, vol. 48, no. 6, pp. 931-937, 2005.

[12] Z. Ding, W. Wang, B. Wang et al., "Production and characterization of milk-clotting enzyme from Bacillus amyloliquefaciens JNU002 by submerged fermentation," European Food Research and Technology, vol. 234, no. 3, pp. 415-421, 2012.

[13] N. Liu and R. Arutselvi, "Partial purification and characterization of protease enzyme from Nomurarea rileyi," International Journal of Pharmaceutical Sciences, vol. 4, no. 9, pp. 3460-3465, 2013.

[14] K. Arima, J. Yu, and S. Iwasaki, "Milk-clotting enzyme from Mucor pusillus var. Lindt," Methods in Enzymology, vol. 19, pp. 446-459, 1970.

[15] AOAC, American Official Methods of Analysis, International Association of Official Analytical Chemists, AOAC, Washington DC, USA, 20th edition, 2010.

[16] J. Wangoh, Cheese Production Manual, Department of Food Technology and Nutrition, University of Nairobi, Nairobi, Kenya, 2005.

[17] A. M. E. Sulieman, R. A. M. Ali, and K. A. A. Razig, "Production and effect of storage in the chemical composition of mozzarella cheese," International Journal of Food Science and Nutrition Engineering, vol. 2, no. 3, pp. 21-26, 2012.

[18] A. Singh, M. Agrawal, and F. M. Marshall, "The role of organic vs . inorganic fertilizers in reducing phytoavailability of heavy metals in a wastewater-irrigated area," Ecological Engineering, vol. 36, no. 12, pp. 1733-1740.

[19] W. J. Koe, "Regulations of the European Union for mycotoxins in foods," Arh Hig Rada Toksikol, vol. 50, no. 1, pp. 37-46, 1999.

[20] R. J. S. Castro, T. G. Nishide, and H. H. Sato, "Production and biochemical properties of proteases secreted by Aspergillus niger under solid state fermentation in response to different agroindustrial substrates," Biocatal Agric Biotechnol, vol. 3, no. 4, pp. 236-245, 2014.

[21] E. Ichishima, "Bioscientific topics concerning Aspergillus oryzae, the national microorganism of Japan," Journal of Biochemistry and Biotechnology, vol. 1, no. 1, pp. 42-46, 2018.

[22] V. Kumar, D. Singh, P. Sangwan, and K. Gill, "Global market scenario of industrial enzymes," in Industrial Enzymes Trends, Scope, and Relevances, V. Beniwal, Ed., pp. 173-194, Nova Science Publishers Inc., New York, NY, USA, 2014.

[23] H. Kumura, C. Saito, and Y. Taniguchi, "Adjunctive application of solid-state culture products from Aspergillus oryzae for semi-hard cheese," Advances in Dairy Research, vol. 5, no. 3, pp. 1-7, 2017.

[24] F. Fazouane-Naimi, A. Mechakra, R. Abdellaoui et al., "Characterization and cheese-making properties of rennet- like enzyme produced by a local Algerian isolate ofAspergillus Niger," Food Biotechnology, vol. 24, no. 3, pp. 258-269, 2010.

[25] M. B. Gais Güler-Akın, "Effects of coagulating enzyme types (commercial calf rennet, Aspergillus niger var. awamori as recombinant chymosin and Rhizomucor miehei as microbial rennet) on the chemical and sensory characteristics of white pickled cheese," African Journal of Biotechnology, vol. 12, no. 37, pp. 5588-5594, 2013.

[26] L. S. Alves, C. Merheb-Dini, E. Gomes, R. da Silva, and M. L. Gigante, "Yield, changes in proteolysis, and sensory quality of Prato cheese produced with different coagulants," Journal of Dairy Science, vol. 96, no. 12, pp. 7490-7499, 2013.

[27] J. O. Gigante, O. M. Ighordaro, and M. O. Mathew, "Proximate composition of whey from southwest Nigeria," Advanced Biomedical Research, vol. 3, no. 1, pp. 14-16, 2012.

[28] I. A. A. A. Ayana, A. E. Ibrahim, and W. I. A. Saber, "Statistical optimization of milk clotting enzyme biosynthesis by Mucor mucedo Kp736529 and its further application in cheese production," International Journal of Dairy Science, vol. 10, no. 2, pp. 61-76, 2015.

[29] L. Darnay, F. Králik, G. Oros, Á. Koncz, and F. Firtha, "Monitoring the effect of transglutaminase in semi-hard cheese during ripening by hyperspectral imaging," Journal of Food Engineering, vol. 196, pp. 123-129, 2017.

[30] S. Yegin, M. Fernández-Lahore, U. Guvenc, and G. Yekta, "Production of extracellular aspartic protease in submerged fermentation with Mucor mucedo DSM 809," African Journal of Biotechnology, vol. 9, no. 38, pp. 6380-6386, 2010.

[31] M. B. Rao, A. M. Tanksale, M. S. Ghatge, and V. V. Deshpande, "Molecular and biotechnological aspects of microbial proteases," Microbiology and Molecular Biology Reviews, vol. 62, no. 3, pp. 597-635, 1998.

[32] R. Garc' 1a, B. Teruel, R. Rodr' 1guez, and M. L'opez, "Effect of vegetable coagulant, microbial coagulant and calf rennet on physicochemical, proteolysis, sensory and texture profiles of fresh goats cheese," Dairy Science \& Technology, vol. 92, no. 6, pp. 691-707, 2012.

[33] S. A. Ahmed, H. R. Wehaidy, O. A. Ibrahim, S. Abd El Ghani, and M. A. El-Hofi, "Novel milk-clotting enzyme from Bacillus stearothermophilus as a coagulant in UF-white soft cheese," Biocatalysis and Agricultural Biotechnology, vol. 7, pp. 241249, 2016.

[34] C. Merheb-dini, G. A. C. Garcia, A. L. B. Penna, E. Gomes, R. da Silva, and E. Gomes, "Use of a new milk-clotting protease from Thermomucor indicae-seudaticae N31 as coagulant and changes during ripening of Prato cheese," Food Chemistry, vol. 130, no. 4, pp. 859-865, 2012.

[35] M.-R. Lee, "Changes in the mineral components in cheese juice (aqueous phase of cheese) during ripening," Journal of Milk Science and Biotechnology, vol. 35, no. 2, pp. 85-92, 2017.

[36] E. Gore, J. Mardon, D. Guerinon, and A. Lebecque, "Exploratory study of acid-forming potential of commercial cheeses: impact of cheese type," International Journal of Food Sciences and Nutrition, vol. 67, no. 4, pp. 412-421, 2016.

[37] I. González-Martín, J. M. Hernández-Hierro, I. Revilla, A. Vivar-quintana, and I. Lobos Ortega, "The mineral composition (Ca, P, Mg, K, Na) in cheeses (cow's, Ewe's and goat's) with different ripening times using near infrared spectroscopy with a fibre-optic probe," Food Chemistry, vol. 127, no. 1, pp. 147-152, 2011.

[38] D. A. Jaoude, A. Olabi, N. El et al., "Chemical composition, mineral content and cholesterol levels of some regular and reduced-fat white brined cheeses and strained yogurt 
(Labneh)," Dairy Science \& Technology, vol. 90, no. 6, pp. 699-706, 2010.

[39] M. Mattera, A. Durazzo, S. Nicoli, M. G. D. I. Costanzo, and P. Manzi, "Chemical, nutritional, physical, and antioxidant properties of pecorino," Italian Journal of Food Science, vol. 28, pp. 579-597, 2016.

[40] A. J. Cichoscki, E. Valduga, A. T. Valduga, M. E. Tornadijo, and J. M. Fresno, "Characterization of Prato cheese, a Brazilian semi-hard cow variety: evolution of physico-chemical parameters and mineral composition during ripening," Food Control, vol. 13, no. 4-5, pp. 329-336, 2002.

[41] M. A. Murtaza, N. Huma, A. Sameen, M. Saeed, and M. S. Murtaza, "Minerals and lactic acid contents in buffalo milk cheddar cheese, a comparison with cow," Journal of Food and Nutrition Research, vol. 2, no. 8, pp. 465-468, 2014. 